\title{
The clinical utility of structural neuroimaging in first episode psychosis: a systematic review
}

\begin{abstract}
Background: Australian and US guidelines recommend routine brain imaging, either computed tomography (CT) or magnetic resonance imaging (MRI), to exclude structural lesions in presentations for first-episode psychosis. The aim of this review was to examine the evidence for the appropriateness and clinical utility of this recommendation by assessing the frequency of abnormal radiological findings in CT and MRI scans among patients with firstepisode psychosis.
\end{abstract}

Methods: PubMed and Embase database were searched from inception to April 2018 using appropriate $\mathrm{MeSH}$ or Emtree terms. Studies were included in the review if they reported data on CT or MRI scan findings of individuals with first-episode psychosis. No restriction on the geographical location of the study or the age of participants was applied. We calculated the percentage of abnormal radiological findings in each study, separately by the two diagnostic methods.

Results: There were 16 suitable studies published between 1988 and 2017, reporting data on an overall 2312 patients with first-episode psychosis. Most were observational studies with retrospective design and majority examined patients with CT. While structural abnormalities were a relatively common finding, these rarely required clinical intervention (range across studies: $0-60.7 \%$; median: $3.5 \%$ ) and were very rarely the cause of the psychotic symptoms (range: 0-3.3\%; median: 0\%). Only two of the 16 studies concluded that brain imaging should be routinely ordered in first-episode psychosis.

Conclusion: There is insufficient evidence to suggest that brain imaging should be routinely ordered for patients presenting with first-episode psychosis without associated neurological or cognitive impairment. The appropriate screening procedure for structural brain lesions is conventional history-taking, mental status, and neurological examination. If intracranial pathology is suspected clinically, an MRI or CT scan should be performed depending on the clinical signs, the acuity and the suspected pathology. National guidelines should reflect evidence-based data. 


\section{Introduction}

Since Weinberger first proposed the use of computed tomography in first-episode psychosis in 1984, neuroimaging has been part of the medical work-up of these cases to exclude contributory neurological conditions (Weinberger, 1984). Recommendations for brain imaging have been incorporated into practice guidelines although considerable disparity remains among national guidelines about whether scanning should be routinely undertaken (Table 1).

The aim of this study is to systematically review the evidence for the clinical utility of computed tomography (CT) or magnetic resonance imaging (MRI) in first-episode psychosis. In particular, we assessed the frequency of abnormal radiological findings in CT and MRI scans among patients who were admitted to hospital with first-episode psychosis. This review updates previous reviews by Albon et al. (2008) Goulet et al (2009) and The National Institute for Health and Care Excellence (NICE, 2011) with new data. All of these reviews have concluded that routine neuroimaging is not indicated in first-episode psychosis.

\section{Method}

The methods are based on the Preferred Reporting Items for Systematic Review and Meta-Analyses (PRISMA) (Moher et al., 2009). We searched PubMed and Embase up to April 2018 using the following text, MeSH or Emtree terms as appropriate: (early OR first OR firstepisode OR "first episode") AND (psychosis OR psychotic OR schizophreniform) AND (neuroimaging OR "brain imaging" OR CT OR MRI OR "computed tomography" OR "magnetic resonance imaging"). The initial search was performed by MF. The selected abstracts (109 papers) were reviewed by MF, DS and MB to determine if they met inclusion criteria. We (MF, DS, MB) searched for further publications by scrutinising the reference lists of initial studies identified and other relevant review papers. MF contacted selected authors and experts to obtain further data where necessary. Radiological findings were classified by two authors (DV, SS). Conflicts between the three reviewers were resolved by discussion.

Our inclusion criteria were as follows: retrospective or prospective studies with primary data collection that included data on the radiological findings in individuals with first-episode psychosis. We applied no restriction on the geographical location of the study or the age of participants. We excluded studies that did not specifically state participants had first-episode psychosis and excluded morphological brain studies that provided volumetric or other data but did not provide radiological diagnosis. Only English-language studies were included. 
In the data extraction phase, information on study design, number, age and sex of participants, as well as on the field-strength of MRI scan methods (if available) was collected from all included studies. We utilised the same methodology as used by Goulet et al (2009) and classified brain scans as:

1. Normal;

2. Abnormal, with radiological findings having no clinical impact: benign or nonspecific findings with no implication on diagnosis, management, or treatment;

3. Abnormal, with radiological findings having an implication on management or treatment, but an unlikely causal link to psychotic symptoms;

4. Abnormal, with radiological findings having an implication on management or treatment, and a possible causal link to psychotic symptoms.

The number of patients who belonged to any of the above categories, together with their radiological diagnosis in case of abnormal findings, was extracted from each study. From this information, we calculated the percentage of patients with these outcomes from all scanned individuals. Data are presented separately in each study by CT and MRI scans. The data extraction procedure was led by the first author (MF), but DS and MB also checked the accuracy of reported values.

We (MF, DS, MB) independently assessed methodological quality using a modified version of quality assessment tool used by Rao et al (2005) which rates studies examining the clinical utility of a test based on details of study sample and patient selection, data collection, and verification and details of the test (Table 2).

\section{Results}

There were 2314 citations of interest in the initial electronic searches, of which 109 abstracts were screened. Of these, 22 full-text papers were potentially relevant and assessed for eligibility. Nine papers were excluded for reasons listed in Figure 1. Three additional papers were found from the reference lists of other papers from the database search. This left 16 papers, six which were published since the most recent review (NICE, 2011) (Figure 1). For each paper, the percentage of participants with the specific outcome was provided according to the classification system outlined above. 
Thirteen of the 16 studies were retrospective audits of medical records, two were prospective case series and one was a case-control study (Table 3). Sample sizes ranged from 30 to 349, and overall, they examined 2312 patients. Two studies considered the diagnostic characteristics of tests (sensitivity, specificity) and the costs of potentially unnecessary scans but none provided details or an economic analysis. None of the studies gave follow-up data and none were randomised controlled trials or before-after studies. Six papers came from the United States, three from Australia, two each from the UK and Canada, and one from Switzerland, the Netherlands and Portugal.

The included studies were of variable quality. From the maximum possible quality score of six points, seven studies scored four or five, and were considered as adequate or high quality. On the other hand, six of the reviewed studies had an overall score of one or two, suggesting low quality (Table 4).

\section{Computed tomography}

In one retrospective analysis (Bain, 1998) there were 4 incidental radiological abnormalities of 127 individuals scanned, none of which were causally related to psychosis while in another of 52 patients with first-episode psychosis (McKay et al., 2006), none had abnormalities potentially related to psychosis. The same finding was made in a retrospective analyses of 75 patients (Compton et al., 2009) and of 98 patients (Adams et al., 1996). Further, Strahl et al (2010) reviewed 237 consecutive patients who had CT scans for first-episode psychosis with no focal neurological signs. None of those scanned had abnormalities related to psychosis.

In a retrospective analysis (Gewirtz et al., 1994) one of the 168 individuals scanned $(0.6 \%)$ had incidental findings that may have been causally related to psychosis. Individuals were examined but it is unclear whether neurological findings on clinical examination were present in the individuals with psychosis. In another study, this time a prospective diagnostic case series (Battaglia and Spector, 1988), three of 45 individuals had incidental abnormalities although none of these abnormalities considered implicated in psychosis. This study excluded individuals with drug-induced psychosis, thus the 'hit rate' for identifying lesions responsible for psychosis was likely higher than studies that did not exclude this group.

\section{Magnetic resonance imaging}


Borgwardt et al (2006) used MRI to assess the prevalence of radiological abnormalities in individuals with first-episode psychosis and compared this to individuals at high risk of schizophrenia. The rate of radiological abnormality in the first-episode psychosis group was $40 \%$, but only 2 of the 30 individuals with first episode psychosis had clinically relevant pathology - a subdural effusion and right temporal hamartoma. The authors did not identify whether these individuals had findings on neurological examination.

Similarly, a case-control study of a clinical and community-based sample found radiological abnormalities in $15 \%$ of the former and $6 \%$ of the community-based sample although none of the abnormalities required intervention or were related to psychosis (Falkenberg et al., 2017). Despite this finding, the authors concluded by recommending routine MRI in the clinical assessment of all patients presenting with first episode psychosis.

A further study used a research sample that excluded individuals with a history of head injury, seizures, neurological disease and alcohol or substance use disorder (Lubman et al., 2002). The authors classified abnormalities as requiring no referral, routine referral or urgent referral. In re-examining the cases identified in their sample, two of 152 cases (1.3\%) may have potentially been casually related to psychosis.

Finally, retrospective reviews of the medical records of 349 (Sommer et al., 2013) and 121 (Pientka et al., 2017) patients with first-episode psychosis found no abnormalities related to psychosis.

\section{Both imaging modalities (CT and MRI)}

Khandanpour et al (2013) retrospectively reviewed 112 consecutive MRI scans and 204 consecutive CT scans for individuals with first-episode psychosis but no neurological signs. Three of 112 (2.7\%) individuals who had MRI and three of 204 (1.5\%) individuals who had CT had incidental brain lesions potentially accountable for psychosis. This study included older patients who were more likely to have an organic cause for psychosis. A second retrospective review of 32 consecutive admissions who received a CT, MRI or both, found none had incidental brain abnormalities potentially accountable for psychosis (Coentre et al., 2016). Two further retrospective reviews of 46 (44 CT and 2 MRI) (Goulet et al., 2009) and 115 individuals (Robert Williams et al., 2014) with first-episode psychosis reported similar negative findings. 


\section{Discussion}

Clinicians order brain imaging to exclude neurological abnormalities in individuals with first-episode psychosis. However, the available data suggest a disappointing yield from routine neuroimaging in individuals at low risk of a specific brain abnormality.

This systematic review includes 2312 individual patients who were scanned with CT or MRI. While structural abnormalities were a relatively common finding, these rarely required clinical intervention (range across studies: 0-60.7\%; median: $3.5 \%$ ) and were very rarely the cause of the psychotic symptoms (range: 0-3.3\%; median: 0\%). Across all studies, only 10 of the 2312 individual subjects had abnormalities that may have been causally related to psychosis $(0.4 \%)$. It is apparent that incidental radiological abnormalities are more common in older individuals, as has been identified in a large meta-analysis of 20,000 individuals (Morris et al., 2009). This review therefore supports the conclusion by Hollister and Boutros (1991) that older age is most predictive of abnormalities in individuals with first-episode psychosis.

The clinical utility of a test is related to its diagnostic utility. The diagnostic utility of a screening test, such as brain imaging in first episode psychosis, depends on a number of variables including the sensitivity and specificity of the test, the prevalence of the disease being tested for and the positive predictive value of the test (Adams et al., 1996). The imaging modality used will thus have an impact on the number and type of abnormalities detected. This is demonstrated in Khandanpour (2013), where more lesions were detected with MRI versus CT and in Falkenberg (2017), where the group scanned with 3-T MRI had more abnormal scans than those scanned with 1.5-T MRI scans. Other factors which may explain the wide variation of abnormalities reported across studies are the prevalence of the abnormalities being tested for and the variation in training, experience and reporting methods of the reporting radiologist(s). As outlined, the prevalence of neurological conditions explaining psychosis is low, although it increases in older individuals. Given the low positive predictive value in firstonset psychosis in adolescents, false-positive tests will be more common than true-positive tests (Adams et al., 1996). In 1000 healthy volunteers, 82\% of MRI scans were completely normal. Of the 'abnormal scans' only $1.1 \%$ required urgent referral, with the remainder representing false-positive tests that may have caused worry (Katzman et al., 1999).

Clinicians continue to order neuroimaging because of clinical practice guidelines, the desire to establish the 'functional' character of the psychosis, and a fear of missing a potentially treatable cause of psychosis or serious neurological illness, which may result in medicolegal 
risk (Freudenreich et al., 2009). This may relate to availability bias in the clinician due to a misperception of how common causative 'organic' findings are, in part due to case reports that resonate with clinicians (Rebecca, 2014, John et al., 2017).

Given the growing amount of data demonstrating the low clinical yield of neuroimaging in first-episode psychosis, the Canadian Psychiatric Association has recently modified its guidelines from an earlier recommendation that brain imaging be considered as part of a routine investigation of all patients with first episode psychosis (Addington et al., 2017). The Canadian guidelines now state that 'imaging is indicated in the presence of signs and symptoms suggestive of intracranial pathology including headaches, nausea and vomiting, seizure-like activity, and later age at the onset of symptoms' (Addington et al., 2017). This is reflected in the recommendations of Choosing Wisely in both Canada and the United Kingdom that clinicians do not routinely order neuroimaging in first-episode psychosis in the absence of signs or symptoms suggestive of intracranial pathology (Choosing Wisely Canada, 2017, Choosing Wisely UK, 2018). The recommendation of the American Psychiatric Association Practice Guidelines for the Psychiatric Evaluation of Adults is that 'the decision to do laboratory studies and other clinical tests, such as imaging studies... should be based on the likelihood that the test result will alter diagnostic or treatment-related decision making. The costs of "routine" testing, in financial terms and in unneeded evaluations for false positive results, are unlikely to offset the benefits of untargeted testing' (American Psychiatric Association, 2016). Our results support this statement with respect to brain imaging in first-episode psychosis. Based on the available data, it should not be routinely performed. Prospective studies may provide further higher quality data to inform clinical practice (Jonsdottir and Briem, 2016).

The Royal Australian and New Zealand College of Psychiatrists (RANZCP) guidelines highlight the difference in opinion on the need for brain imaging (Galletly et al., 2016). In contrast to this uncertainty and the outright opposition to routine scanning in all cases of first episode psychosis in UK and Canadian guidelines, the Australian Orygen guidelines, updated in 2016, continue to recommend neuroimaging in first-episode psychosis (Orygen National Centre of Excellence in Youth Mental Health, 2016). This recommendation is not supported by the findings of this review.

While there are research indications for brain imaging in first-episode psychosis, these have only identified abnormalities at an aggregated population level rather than in clinical settings (Fusar-Poli and Meyer-Lindenberg, 2016, Bartholomeusz et al., 2017). There is no 
evidence to support the use of voxel-based morphology to diagnose schizophrenia in patients with first-episode psychosis (Palaniyappan et al., 2015).

Even with 6 more studies than earlier reviews, there were only 16 papers, a low number considering all MRI studies on FEP. There were limitations in the available studies. Most had methodological problems, were of retrospective design and of heterogenous populations. It was not clear in several studies whether the same CT or MRI machine was used, what type of machine was used or whether scans were reported by the same neuroradiologist. There was a risk of selection bias in some studies where patients were included in a non-consecutive manner. There was also unclear documentation about whether a neurological examination was performed in all studies. No studies provided details of diagnostic measures (sensitivity, specificity or area under the curve) or economic analysis.

\section{Conclusion}

While clinicians must remain cognisant that patients presenting with first-episode psychosis have higher rates of underlying neurological abnormalities compared to healthy individuals, the available data do not support routine ordering of brain imaging for first-episode psychosis in the absence of clinical signs, symptoms or antecedents suggestive of an underlying medical or neurological disorder. The appropriate screening procedure for structural brain lesions is conventional history-taking, mental status, and neurological examination. If intracranial pathology is suspected clinically, an MRI or CT scan should be performed depending on the clinical signs, the acuity and the suspected pathology.

\section{Conflict of interest statement}

There are no actual or potential conflicts of interests related to this manuscript.

\section{Funding}

No external funding was used to carry out this study. 


\section{Figures}

Figure 1: Search strategy

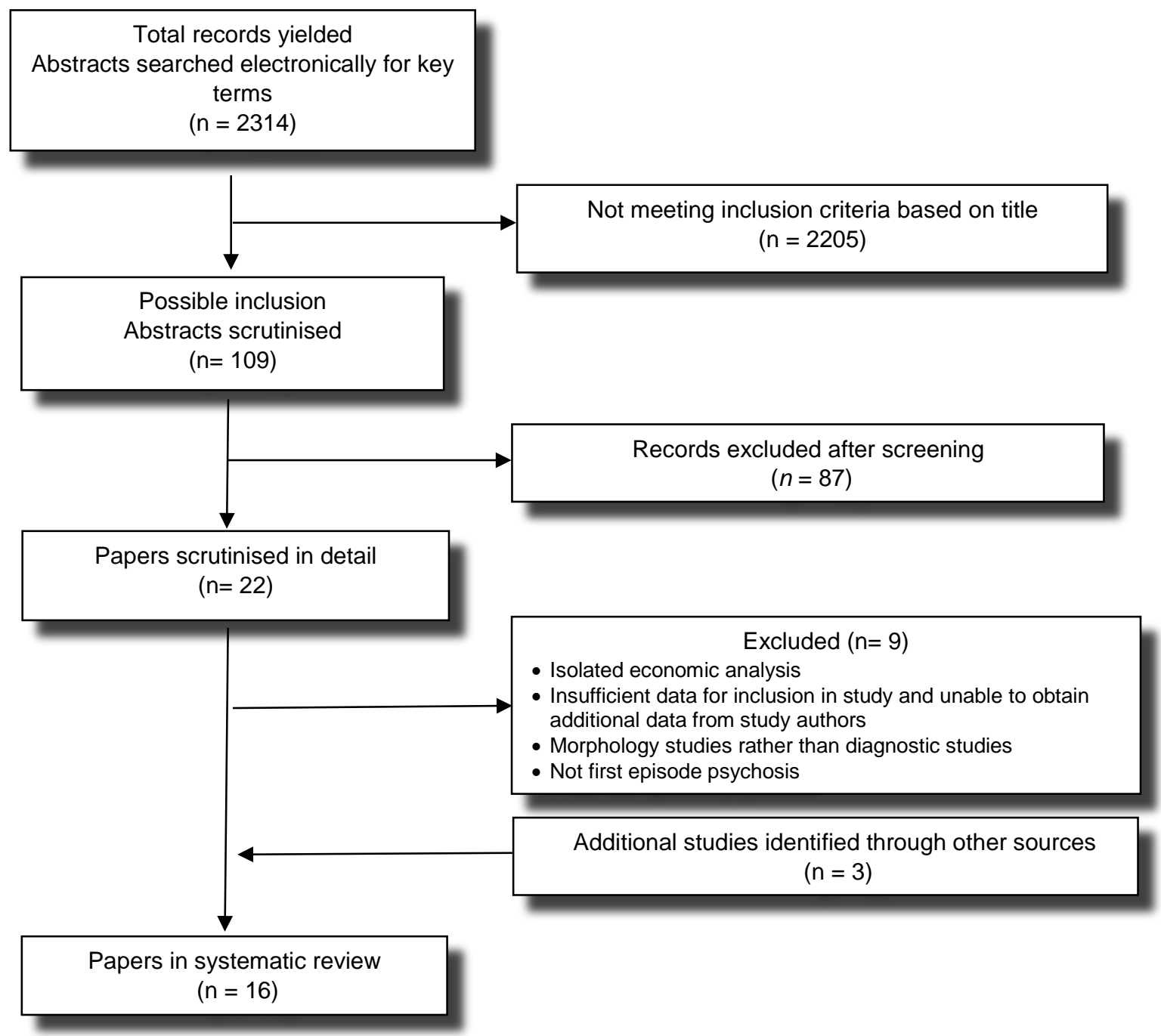




\section{Tables}

Table 1: Guidance about neuroimaging in first-episode psychosis

\begin{tabular}{|c|c|}
\hline Guideline & Recommendation \\
\hline $\begin{array}{l}\text { American Psychiatric Association } \\
\text { Guidelines for the Treatment of Patients } \\
\text { with Schizophrenia, Second Edition, } \\
2010 \quad \text { (American Psychiatric } \\
\text { Association, 2010) }\end{array}$ & $\begin{array}{l}\text { A CT or MRI scan may provide helpful } \\
\text { information, particularly in assessing patients } \\
\text { with a new onset of psychosis or with an atypical } \\
\text { clinical presentation. Although imaging studies } \\
\text { cannot establish a diagnosis of schizophrenia, } \\
\text { specific findings from a CT or MRI scan (e.g., } \\
\text { ventricular enlargement, diminished cortical } \\
\text { volume) may enhance the confidence of the } \\
\text { diagnosis and provide information that is relevant } \\
\text { to treatment planning and prognosis. Given the } \\
\text { subtle nature of the neuropathological findings in } \\
\text { schizophrenia, MRI is preferred over CT. }\end{array}$ \\
\hline $\begin{array}{l}\text { Australian Clinical Guidelines for Early } \\
\text { Psychosis, } 2016 \quad \text { (Orygen National } \\
\text { Centre of Excellence in Youth Mental } \\
\text { Health, 2016) }\end{array}$ & $\begin{array}{l}\text { The following are recommended for all people } \\
\text { admitted to an early psychosis service (ultra-high } \\
\text { risk or first-episode psychosis): MRI }\end{array}$ \\
\hline $\begin{array}{l}\text { Royal Australian and New Zealand } \\
\text { College of Psychiatrists clinical } \\
\text { practice guidelines for the management } \\
\text { of schizophrenia and related disorders } \\
\text { (Galletly et al., 2016) }\end{array}$ & $\begin{array}{l}\text { A comprehensive assessment including physical } \\
\text { health screening is essential. Expert opinion is } \\
\text { divided about whether an MRI scan of the brain } \\
\text { is necessary for all people with first-episode } \\
\text { psychosis. }\end{array}$ \\
\hline $\begin{array}{l}\text { Canadian Guidelines for the Assessment } \\
\text { and Diagnosis of Patients with } \\
\text { Schizophrenia Spectrum and Other } \\
\text { Psychotic Disorders, } 2017 \text { (Addington et } \\
\text { al., 2017) }\end{array}$ & $\begin{array}{l}\text { Order neuroimaging with computed tomography } \\
\text { or magnetic resonance imaging based on specific } \\
\text { aspects of the history, neurological examination, } \\
\text { or neuropsychological testing results. Consider } \\
\text { on a case-by-case basis at the time of the first } \\
\text { episode of psychosis. }\end{array}$ \\
\hline $\begin{array}{l}\text { National Institute for Health and Care } \\
\text { Excellence Guidance for structural }\end{array}$ & $\begin{array}{l}\text { Structural neuroimaging techniques (either } \\
\text { magnetic resonance imaging }[\mathrm{MRI}] \text { or computed }\end{array}$ \\
\hline
\end{tabular}


neuroimaging in first-episode psychosis, 2011 (NICE, 2011) axial tomography [CT] scanning) are not recommended as a routine part of the initial investigations for the management of firstepisode psychosis.

Table 2: Quality assessment of methodologic quality

\begin{tabular}{|l|l|l|}
\hline Study characteristic & $\mathbf{1}$ point & 0 points \\
\hline Study sample & Clinical sample & Community-based sample \\
\hline Details of the study sample & $\begin{array}{l}\text { Sufficient details of study } \\
\text { and/or control populations }\end{array}$ & $\begin{array}{l}\text { Insufficient details of study } \\
\text { and/or control populations }\end{array}$ \\
\hline $\begin{array}{l}\text { Verification / test } \\
\text { interpretation }\end{array}$ & $\begin{array}{l}\text { Independent } \\
\text { neuroradiologist reviewing } \\
\text { finding }\end{array}$ & Other / not stated \\
\hline Patient selection & Consecutive & Non-consecutive \\
\hline Data collection & Prospective & Non-prospective \\
\hline Details of test & $\begin{array}{l}\text { Sufficient details of } \\
\text { diagnostic test }\end{array}$ & $\begin{array}{l}\text { Insufficient details of } \\
\text { diagnostic test }\end{array}$ \\
\hline
\end{tabular}


Table 3: Radiological findings

\begin{tabular}{|c|c|c|c|c|c|c|c|c|c|c|}
\hline Study & Study design & $\mathbf{N}$ & $\begin{array}{l}\text { Age } \\
\text { (mean } \\
\text { [range or } \\
\text { SD]) }\end{array}$ & $\begin{array}{l}\text { Sex } \\
\text { (M:F) }\end{array}$ & $\begin{array}{l}\text { Field } \\
\text { Strength } \\
\text { (MRI) }\end{array}$ & $\begin{array}{l}\text { Normal } \quad(n / N \text {, } \\
\%)\end{array}$ & $\begin{array}{l}\text { Abnormal, benign and/or } \\
\text { nonspecific }(\mathrm{n} / \mathrm{N}, \%)\end{array}$ & $\begin{array}{l}\text { Abnormal, may modify } \\
\text { management } \begin{array}{r}\text { and } \\
\text { treatment, but unlikely } \\
\text { causal link to psychosis } \\
(\mathrm{n} / \mathrm{N}, \%)\end{array}\end{array}$ & $\begin{array}{l}\text { Abnormal, may } \\
\text { modify management } \\
\text { treatment, possible } \\
\text { causal link to } \\
\text { psychosis }(\mathrm{n} / \mathrm{N}, \%) \\
\end{array}$ & $\begin{array}{l}\text { Limitations } \\
\text { Comments }\end{array}$ \\
\hline $\begin{array}{l}\text { Adams } \\
1996 \\
\text { (Canada) }\end{array}$ & $\begin{array}{l}\text { Retrospective } \\
\text { review of } \\
\text { medical of } \\
\text { records of } \\
\text { patients with } \\
\text { CT scans; no } \\
\text { control group } \\
\end{array}$ & 98 & $13-19$ & $\begin{array}{l}\text { Not } \\
\text { present }\end{array}$ & $\mathrm{N} / \mathrm{A}$ & & & & $0 / 98,0 \%$ & $\begin{array}{l}\text { Limited data available on } \\
\text { individual patient scans }\end{array}$ \\
\hline $\begin{array}{l}\text { Bain } 1998 \\
\text { (USA) }\end{array}$ & $\begin{array}{l}\text { Retrospective } \\
\text { review of } \\
\text { medical of } \\
\text { records of } \\
\text { patients with } \\
\text { CT scans; no } \\
\text { control group } \\
\end{array}$ & 127 & $\begin{array}{l}98 \text { aged } \\
17-30 ; \\
23 \text { aged } \\
31-40 ; \\
6 \quad \text { aged } \\
41+\end{array}$ & $102: 25$ & $\mathrm{~N} / \mathrm{A}$ & $\begin{array}{l}123 / 127 \\
96.9 \%\end{array}$ & $\begin{array}{l}\text { 3/127, } 2.4 \% \\
\text { - } 1 \text { punctate calcification in } \\
\text { right frontal deep white } \\
\text { matter } \\
\text { - } 1 \text { arachnoid cyst } \\
\text { - } 1 \text { left posterior fossa } \\
\text { arachnoid cyst }\end{array}$ & $\begin{array}{l}1 / 127,0.8 \% \\
\text { - } 1 \text { suspected pineal } \\
\text { gland tumour, } \\
\text { subsequent MRI normal }\end{array}$ & $0 / 127,0 \%$ & $\begin{array}{l}\text { Retrospective design } \\
\text { Single location }\end{array}$ \\
\hline $\begin{array}{l}\text { Battaglia } \\
1988 \\
\text { (USA) }\end{array}$ & $\begin{array}{l}\text { Prospective } \\
\text { diagnostic } \\
\text { case series } \\
\text { with CT; no } \\
\text { control group }\end{array}$ & 45 & $\begin{array}{l}26 \\
{[17-54]}\end{array}$ & $30: 15$ & $\mathrm{~N} / \mathrm{A}$ & 42/45, 93.3\% & $\begin{array}{l}1 / 45,2.2 \% \\
\cdot 1 \text { mild cortical atrophy }\end{array}$ & $\begin{array}{l}\text { 2/45, } 4.4 \% \\
\text { - } 1 \text { possible right frontal } \\
\text { white matter infarct } \\
\text { - } 1 \text { possible left caudate } \\
\text { infarct }\end{array}$ & $0 / 45,0 \%$ & $\begin{array}{l}\text { Small sample } \\
\text { Single location }\end{array}$ \\
\hline $\begin{array}{l}\text { Borgwardt } \\
2006 \\
\text { (Switzerla } \\
\text { nd) }\end{array}$ & $\begin{array}{l}\text { Prospective } \\
\text { diagnostic } \\
\text { case series } \\
\text { with MRI; } \\
\text { control group }\end{array}$ & 30 & $30.3[6.9]$ & $22: 8$ & 1.5T MRI & $18 / 30,60 \%$ & $\begin{array}{l}12 / 30,40 \% \\
\text { - } 3 \text { generalised atrophy } \\
\text { - } 3 \text { neuroepithelial cyst } \\
\text { - } 2 \text { frontal atrophy } \\
\text { - } 2 \text { single hyperintense } \\
\text { lesions } \\
\text { - } 1 \text { arachnoid cyst } \\
\text { - } 1 \text { cavum septi pellucidi } \\
\end{array}$ & $\begin{array}{l}1 / 30,3.3 \% \\
\text { - } 1 \text { subdural effusion }\end{array}$ & $\begin{array}{l}1 / 30,3.3 \% \\
-\quad 1 \text { right temporal } \\
\text { hamartoma }\end{array}$ & Small sample \\
\hline $\begin{array}{l}\text { Coentre } \\
2016 \\
\text { (Portugal) }\end{array}$ & \begin{tabular}{l}
\multicolumn{3}{l}{ Retrospective } \\
review of \\
medical \\
records of \\
patients with \\
CT or MRI \\
scan; no \\
control group \\
\end{tabular} & $\begin{array}{l}32 \\
(29 \\
\text { CT, } \\
1 \\
\text { MRI, } \\
2 \\
\text { both } \\
) \\
\end{array}$ & $\begin{array}{l}29.6[18- \\
48,8.7]\end{array}$ & $19: 13$ & 1.5T MRI & $20 / 32,62.5 \%$ & $\begin{array}{l}12 / 32,37.5 \% \\
\text { - } 4 \text { cerebral atrophy } \\
\text { - } 3 \text { arachnoid cyst } \\
\text { - } 2 \text { asymmetrical lateral } \\
\text { ventricles } \\
\text { - } 1 \text { dilated ventricles } \\
\text { - } 1 \text { plagiocephaly } \\
\text { - } 1 \text { falx cerebri calcification }\end{array}$ & $0 / 32,0 \%$ & $0 / 32,0 \%$ & $\begin{array}{l}\text { Retrospective design } \\
\text { Small sample }\end{array}$ \\
\hline $\begin{array}{l}\text { Compton } \\
2009 \\
\text { (USA) }\end{array}$ & \begin{tabular}{l}
\multicolumn{2}{l}{ Retrospective } \\
review of \\
medical \\
records of \\
\end{tabular} & 75 & $\begin{array}{l}22.7[18- \\
40,4.2]\end{array}$ & 54:21 & $\mathrm{N} / \mathrm{A}$ & $19 / 75,25.3 \%$ & $\begin{array}{l}56 / 75,74.7 \% \\
\text { - } 39 \text { pineal or epithalamus } \\
\text { calcification }\end{array}$ & $0 / 75,0 \%$ & $0 / 75,0 \%$ & Retrospective design \\
\hline
\end{tabular}




\begin{tabular}{|c|c|c|c|c|c|c|c|c|c|c|}
\hline & $\begin{array}{l}\text { patients with } \\
\text { CT; no control } \\
\text { group }\end{array}$ & & & & & & $\begin{array}{l}\text { - } 9 \text { habenula region } \\
\text { calcification } \\
\text { - } 6 \text { brain volume loss } \\
\text { - } 2 \text { cavum septi pellucidum } \\
\text { / cavum vergae }\end{array}$ & & & \\
\hline \multirow[t]{2}{*}{$\begin{array}{l}\text { Falkenber } \\
\text { g } 2017 \\
(\mathrm{UK})\end{array}$} & $\begin{array}{l}\text { Case-control } \\
\text { (community } \\
\text { sample) } \\
\text { MRI scan }\end{array}$ & 108 & \begin{tabular}{l}
\multicolumn{2}{l}{ Median } \\
26 \\
$54] \quad[17-$
\end{tabular} & $71: 37$ & 1.5T MRI & $\begin{array}{l}102 / 108 \\
94.4 \%\end{array}$ & $\begin{array}{l}\text { 2/108, } 1.9 \% \\
\text { - } 2 \text { mild asymmetry of } \\
\text { ventricles, lobes or brain }\end{array}$ & $\begin{array}{l}\text { 4/108, } 3.7 \% \\
\text { - } 2 \text { small benign cyst } \\
\text { - } 1 \text { white matter } \\
\text { abnormality } \\
\text { - } 1 \text { sella (partially) empty }\end{array}$ & $0 / 108,0 \%$ & \\
\hline & $\begin{array}{l}\text { Case-control } \\
\text { (clinical } \\
\text { sample) } \\
\text { MRI scan }\end{array}$ & 241 & \begin{tabular}{l}
\multicolumn{2}{l}{ Median } \\
$24 \quad[14-$ \\
$56]$
\end{tabular} & 162:79 & 3.0T MRI & $\begin{array}{l}204 / 241 \\
84.6 \%\end{array}$ & $\begin{array}{l}\text { 14/241, } 5.8 \% \\
\text { - } 12 \text { cavum septum } \\
\text { pellucidum } \\
\text { - } 2 \text { mild asymmetry of } \\
\text { ventricles, lobes or brain }\end{array}$ & $\begin{array}{l}\text { 23/241, 9.5\% } \\
\text { - } 14 \text { white matter } \\
\text { abnormality } \\
\text { - } 6 \text { small benign cyst } \\
\text { - } 2 \text { sella (partially) empty } \\
\text { - } 1 \text { post-ischaemic lesion }\end{array}$ & $0 / 241,0 \%$ & \\
\hline $\begin{array}{l}\text { Gewirtz } \\
1994 \\
\text { (USA) }\end{array}$ & $\begin{array}{l}\text { Retrospective } \\
\text { review of } \\
\text { medical of } \\
\text { records of } \\
\text { patients with } \\
\text { CT scan; no } \\
\text { control group }\end{array}$ & 168 & $\begin{array}{l}35 \quad[18- \\
66,12]\end{array}$ & 79:89 & N/A & $91 / 168,54.2 \%$ & $\begin{array}{l}\text { 71/168, } 41.1 \% \\
\text { - } 67 \text { diffuse cortical atrophy } \\
\text { - } 2 \text { arachnoid cysts } \\
\text { - } 1 \text { cavum septi pellucidum } \\
\text { and cavum vergae } \\
\text { - } 1 \text { venous angiona }\end{array}$ & $\begin{array}{l}\text { 3/168, 3.0\% } \\
\text { - } 1 \text { old right subcortical } \\
\text { parieto-temporal infarct } \\
\text { - } 1 \text { diffuse white matter } \\
\text { ischaemic change } \\
\text { - } 1 \text { moderate-to-large } \\
\text { temporal arachnoid cyst } \\
\text { in right temporal area } \\
\text { - } 1 \text { old bilateral parietal } \\
\text { infarction and possible } \\
\text { subinsular infarct } \\
\text { - } 1 \text { bilateral parietal } \\
\text { ischaemic changes }\end{array}$ & \begin{tabular}{|l}
$1 / 168,0.6 \%$ \\
-1 third ventricle \\
colloidal cyst with \\
obstruction of \\
foramen of Monro
\end{tabular} & Retrospective design \\
\hline $\begin{array}{l}\text { Goulet } \\
2009 \\
\text { (Canada) }\end{array}$ & \begin{tabular}{l}
\multicolumn{3}{l}{ Retrospective } \\
review of \\
medical \\
records of \\
patients with \\
CT or MRI \\
scan; no \\
control group
\end{tabular} & $\begin{array}{l}46 \\
(44 \\
\mathrm{CT} \\
2 \\
\mathrm{MRI}\end{array}$ & 29.3 & $34: 12$ & $\begin{array}{l}\text { Not } \\
\text { provided }\end{array}$ & $45 / 46,97.8 \%$ & $\begin{array}{l}1 / 46,2.2 \% \\
\bullet \quad 1 \text { small lipoma just } \\
\quad \text { above pineal gland }\end{array}$ & $0 / 46,0 \%$ & $0 / 46,0 \%$ & $\begin{array}{l}\text { Retrospective design } \\
\text { Small sample }\end{array}$ \\
\hline $\begin{array}{l}\text { Khandanp } \\
\text { our } 2012 \\
\text { (UK) }\end{array}$ & \begin{tabular}{lr}
\multicolumn{3}{l}{ Retrospective } \\
review of \\
medical \\
records of \\
patients with \\
CT or \\
scan; \\
control group
\end{tabular} & $\begin{array}{l}316 \\
(204 \\
\text { CT, } \\
112 \\
\text { MRI) }\end{array}$ & $\begin{array}{l}\text { CT } \\
66.8[19- \\
95] \\
\text { MRI } \\
59.3[16- \\
92]\end{array}$ & $\begin{array}{l}\text { CT } \\
84: 120 \\
\text { MRI } \\
70: 42\end{array}$ & $\begin{array}{l}\text { Various } \\
\text { MRI } \\
\text { scanners } \\
\text { used (1.5- } \\
3 \mathrm{~T})\end{array}$ & $\begin{array}{l}\text { CT } \\
68 / 204,33.3 \% \\
\text { MRI } \\
53 / 112,47.3 \%\end{array}$ & $\begin{array}{l}\text { CT } \\
41 / 204,20.1 \% \\
\text { - } 40 \text { cerebral atrophy } \\
\text { - } 1 \text { cavernoma } \\
\text { MRI } \\
47 / 112,42.0 \% \\
\text { - } 37 \text { cerebral atrophy } \\
\text { - } 2 \text { cavernoma } \\
\text { - } 2 \text { cerebral aneurysm }\end{array}$ & $\begin{array}{l}\text { CT } \\
95 / 204,46.6 \% \\
-29 \text { old infarct } \\
-66 \text { small vessel } \\
\quad \text { ischaemic change } \\
\text { MRI } \\
68 / 112,60.7 \% \\
\text { - } 17 \text { old infarct }\end{array}$ & $\begin{array}{l}\text { CT } \\
3 / 204,1.5 \% \\
-1 \text { metastasis } \\
\text { (primary } \\
\text { bronchogenic } \\
\text { carcinoma) } \\
\text { - } 1 \text { meningioma } \\
-1 \text { subependymoma } \\
\text { MRI } \\
\end{array}$ & $\begin{array}{l}\text { Multiple findings } \\
\text { documented for each } \\
\text { patient. }\end{array}$ \\
\hline
\end{tabular}




\begin{tabular}{|c|c|c|c|c|c|c|c|c|c|c|}
\hline & & & & & & & $\begin{array}{l}\text { - } 1 \text { absence of septum } \\
\text { pellucidum } \\
\text { - } 1 \text { basal ganglia } \\
\text { calcification } \\
\text { - } 1 \text { calvarial thickening } \\
\text { - } 1 \text { arachnoid cyst } \\
\text { - } 1 \text { amyloid angiopathy } \\
\text { - } 1 \text { mega cisterna magna } \\
\end{array}$ & $\begin{array}{l}\text { - } 2 \text { old cerebral } \\
\text { haemorrhage } \\
\text { - } 49 \text { small vessel } \\
\text { ischaemic change }\end{array}$ & $\begin{array}{l}\text { 3/112, } 2.7 \% \\
\text { - } 1 \text { HIV } \\
\text { encephalopathy } \\
\text { - } 1 \text { Primary brain } \\
\text { tumour } \\
\text { - } 1 \text { Paramedian } \\
\text { meningioma }\end{array}$ & \\
\hline $\begin{array}{l}\text { Lubman } \\
2002 \\
\text { (Australia) }\end{array}$ & $\begin{array}{l}\text { Retrospective } \\
\text { diagnostic } \\
\text { case series } \\
\text { with MRI; } \\
\text { control group }\end{array}$ & 152 & $21.6[3.5]$ & $104: 48$ & 1.5T MRI & $\begin{array}{l}118 / 152 \\
77.6 \%\end{array}$ & $\begin{array}{l}\text { 21/152, } 13.8 \% \\
\text { - } 7 \text { Prominent sulci / } \\
\text { ventricles } \\
\text { - } 5 \text { white matter } \\
\text { hyperintensity } \\
\text { - } 4 \text { hippocampal asymmetry } \\
\text { - } 1 \text { cerebellar ectopia } \\
\text { - } 1 \text { craniosynostosis } \\
\text { - } 1 \text { chiari } 1 \text { malformation } \\
\text { - } 1 \text { cavum stepi pellucidum } \\
\text { - } 1 \text { cavum of velum } \\
\text { interpositum }\end{array}$ & $\begin{array}{l}\text { 11/152 } 7.2 \% \\
\text { - } 3 \text { pineal cyst } \\
\text { - } 1 \text { possible cortical } \\
\text { dysplasia } \\
\text { - } 1 \text { vascular infarction } \\
\text { - } 1 \text { minimal } \\
\text { communicating } \\
\text { hydrocephalus } \\
\text { - } 1 \text { periventricular } \\
\text { leukomalacia } \\
\text { - } 1 \text { pituitary enlargement } \\
\text { - } 1 \text { possible Huntington's } \\
\text { disease } \\
\text { - } 1 \text { vascular lesion (sulcal } \\
\text { artiovenous } \\
\text { malformation) } \\
\text { - } 1 \text { arachnoid cyst }\end{array}$ & \begin{tabular}{|l|}
$2 / 152,1.3 \%$ \\
$-\quad 2$ possible \\
demyelinating \\
disease
\end{tabular} & \\
\hline $\begin{array}{l}\text { McKay } \\
2006 \\
\text { (Australia) }\end{array}$ & $\begin{array}{l}\text { Retrospective } \\
\text { review of } \\
\text { medical } \\
\text { records of } \\
\text { patients with } \\
\text { CT; no control } \\
\text { group }\end{array}$ & 52 & $15-26$ & & $\mathrm{~N} / \mathrm{A}$ & $47 / 52,90.4 \%$ & $3 / 52,5.8 \%$ & $2 / 52,3.8 \%$ & $0 / 52,0 \%$ & $\begin{array}{l}\text { Retrospective design } \\
\text { Author contacted and } \\
\text { provided clarification }\end{array}$ \\
\hline $\begin{array}{l}\text { Pientka } \\
2017 \\
\text { (USA) }\end{array}$ & \begin{tabular}{lr}
\multicolumn{3}{l}{ Retrospective } \\
review of \\
medical \\
records of \\
patients with \\
MRI; no \\
control group
\end{tabular} & 121 & $12-70$ & $82: 39$ & $\begin{array}{l}\text { Not } \\
\text { provided }\end{array}$ & $\begin{array}{l}\text { 104/121, } \\
86.0 \%\end{array}$ & $\begin{array}{l}\text { 13/121, } 10.7 \% \\
\text { - } 9 \text { Non-specific T2 } \\
\text { hyperintense signal } \\
\text { - } 2 \text { arachnoid cyst } \\
\text { - } 1 \text { venous anomaly } \\
\text { - } 1 \text { cavum septa pellucidum } \\
\text { / cavum vergae }\end{array}$ & $\begin{array}{l}\text { 4/121, } 3.31 \% \\
\text { - } 1 \text { periventricular } \\
\text { leukomalacia } \\
\text { - } 1 \text { sella (partially) empty } \\
\text { - } 1 \text { encephalomalacia } \\
\text { - } 1 \text { white matter vessel } \\
\text { disease }\end{array}$ & $0 / 121,0 \%$ & Retrospective design \\
\hline $\begin{array}{l}\text { Williams } \\
2014 \\
\text { (USA) }\end{array}$ & \begin{tabular}{ll}
\multicolumn{2}{l}{ Retrospective } \\
review of \\
medical \\
records of \\
patients with
\end{tabular} & $\begin{array}{l}115 \\
(93 \\
\mathrm{CT} \\
14 \\
\mathrm{MRI} \\
8\end{array}$ & $12-30$ & & $\begin{array}{l}\text { Not } \\
\text { provided }\end{array}$ & $\begin{array}{l}109 / 115 \\
94.0 \%\end{array}$ & $\begin{array}{l}\text { 5/115, } 4.3 \% \\
\text { - } 1 \text { arachnoid cyst } \\
\text { - } 2 \text { mild cerebral atrophy } \\
\text { - } 1 \text { white matter } \\
\text { hyperintensity }\end{array}$ & $\begin{array}{l}\text { 1/115, } 0.9 \% \\
\text { - } 1 \text { berry aneurysm right } \\
\text { internal carotid }\end{array}$ & $0 / 115,0 \%$ & $\begin{array}{l}\text { Retrospective design } \\
\text { Single location }\end{array}$ \\
\hline
\end{tabular}




\begin{tabular}{|c|c|c|c|c|c|c|c|c|c|c|}
\hline & $\begin{array}{l}\text { CT or MRI; no } \\
\text { control group }\end{array}$ & both & & & & & $\begin{array}{l}\text { - } 1 \text { right temporal lobe } \\
\text { venous angioma }\end{array}$ & & & \\
\hline $\begin{array}{l}\text { Strahl } \\
2010 \\
\text { (Australia) }\end{array}$ & $\begin{array}{l}\text { Retrospective } \\
\text { review of } \\
\text { medical } \\
\text { records of } \\
\text { patients with } \\
\text { CT; no control } \\
\text { group }\end{array}$ & 237 & $\begin{array}{l}28.3[16- \\
72]\end{array}$ & 170:67 & $\mathrm{N} / \mathrm{A}$ & $\begin{array}{l}\text { 192/237, } \\
81.0 \%\end{array}$ & $\begin{array}{l}42 / 237,17.7 \% \\
\text { Including (but not an } \\
\text { exhaustive list) } \\
\text { - } 4 \text { arachnoid cysts } \\
\text { - } 4 \text { cerebral atrophy } \\
\text { - } 4 \text { mild ventricular } \\
\text { asymmetry }\end{array}$ & $\begin{array}{l}\text { 12/237, } 5.1 \% \\
\text { - } 12 \text { old infarcts or small } \\
\text { vessel ischaemic } \\
\text { change }\end{array}$ & $0 / 237,0 \%$ & $\begin{array}{l}\text { Retrospective design } \\
\text { Single location }\end{array}$ \\
\hline $\begin{array}{l}\text { Sommer } \\
2013 \\
\text { (Netherlan } \\
\text { ds) }\end{array}$ & $\begin{array}{l}\text { Retrospective } \\
\text { review of } \\
\text { medical } \\
\text { records of } \\
\text { patients with } \\
\text { MRI; control } \\
\text { group }\end{array}$ & 349 & & & 1.5T MRI & & & & $0 / 349,0 \%$ & $\begin{array}{l}\text { No specific data } \\
\text { provided for the first } \\
\text { episode psychosis group }\end{array}$ \\
\hline
\end{tabular}


Table 4: Quality assessment of included studies

\begin{tabular}{|c|c|c|c|c|c|c|c|}
\hline Study & Population & $\begin{array}{l}\text { Details of } \\
\text { Population }\end{array}$ & Verification & $\begin{array}{l}\text { Patient } \\
\text { selection }\end{array}$ & $\begin{array}{l}\text { Data } \\
\text { collection }\end{array}$ & Details of test & Total Score \\
\hline $\begin{array}{l}\text { Adams (Adams } \\
\text { et al., 1996) }\end{array}$ & 1 & 0 & 0 & 1 & 0 & 0 & 2 \\
\hline $\begin{array}{l}\text { Bain (Bain, } \\
\text { 1998) }\end{array}$ & 1 & 1 & 0 & 0 & 0 & 0 & 2 \\
\hline $\begin{array}{l}\text { Battaglia } \\
\text { (Battaglia and } \\
\text { Spector, 1988) }\end{array}$ & 1 & 1 & 0 & 1 & 1 & 0 & 4 \\
\hline $\begin{array}{l}\text { Borgwardt } \\
\text { (Borgwardt et } \\
\text { al., 2006) }\end{array}$ & 1 & 1 & 1 & 0 & 1 & 1 & 5 \\
\hline $\begin{array}{l}\text { Coentre } \\
\text { (Coentre et al., } \\
2016)\end{array}$ & 1 & 1 & 1 & 1 & 0 & 1 & 5 \\
\hline $\begin{array}{l}\text { Compton } \\
\text { (Compton et } \\
\text { al., 2009) }\end{array}$ & 1 & 1 & 1 & 1 & 0 & 1 & 5 \\
\hline $\begin{array}{l}\text { Falkenberg } \\
\text { (clinical) } \\
\text { (Falkenberg et } \\
\text { al., 2017) }\end{array}$ & 1 & 1 & 1 & 0 & 0 & 1 & 4 \\
\hline $\begin{array}{l}\text { Falkenberg } \\
\text { (community- } \\
\text { based) } \\
\text { (Falkenberg et } \\
\text { al., 2017) }\end{array}$ & 0 & 1 & 1 & 1 & 0 & 1 & 4 \\
\hline $\begin{array}{l}\text { Gewirtz } \\
\text { (Gewirtz et al., } \\
\text { 1994) }\end{array}$ & 1 & 0 & 1 & 1 & 0 & 0 & 3 \\
\hline
\end{tabular}




\begin{tabular}{|c|c|c|c|c|c|c|c|}
\hline $\begin{array}{l}\text { Goulet (Goulet } \\
\text { et al., 2009) }\end{array}$ & 1 & 1 & 0 & 0 & 0 & 0 & 2 \\
\hline $\begin{array}{l}\text { Khandanpour } \\
\text { (Khandanpour } \\
\text { et al., 2013) }\end{array}$ & 1 & 0 & 0 & 1 & 0 & 1 & 3 \\
\hline $\begin{array}{l}\text { Lubman } \\
\text { (Lubman et al., } \\
\text { 2002) }\end{array}$ & 1 & 1 & 1 & 0 & 0 & 1 & 4 \\
\hline $\begin{array}{l}\text { McKay } \\
\text { (McKay et al., } \\
\text { 2006) }\end{array}$ & 1 & 0 & 0 & 0 & 0 & 0 & 1 \\
\hline $\begin{array}{l}\text { Pientka } \\
\text { (Pientka et al., } \\
\text { 2017) }\end{array}$ & 1 & 0 & 0 & 0 & 0 & 0 & 1 \\
\hline Williams (7) & 1 & 0 & 0 & 0 & 0 & 0 & 1 \\
\hline $\begin{array}{l}\text { Strahl (Strahl } \\
\text { et al., 2010) }\end{array}$ & 1 & 0 & 1 & 1 & 0 & 0 & 3 \\
\hline $\begin{array}{l}\text { Sommer } \\
\text { (Sommer et al., } \\
\text { 2013) }\end{array}$ & 1 & 0 & 0 & 1 & 0 & 1 & 3 \\
\hline
\end{tabular}




\section{References}

ADAMS, M., KUTCHER, S., ANTONIW, E. \& BIRD, D. 1996. Diagnostic utility of endocrine and neuroimaging screening tests in first-onset adolescent psychosis. J Am Acad Child Adolesc Psychiatry, 35, 67-73; discussion 73.

ADDINGTON, D., ABIDI, S., GARCIA-ORTEGA, I., HONER, W. G. \& ISMAIL, Z. 2017. Canadian Guidelines for the Assessment and Diagnosis of Patients with Schizophrenia Spectrum and Other Psychotic Disorders. Can J Psychiatry, 62, 594-603.

ALBON, E., TSOURAPAS, A., FREW, E., DAVENPORT, C., OYEBODE, F., BAYLISS, S., ARVANITIS, T. \& MEADS, C. 2008. Structural neuroimaging in psychosis: a systematic review and economic evaluation. Health Technol Assess, 12, iii-iv, ix-163.

AMERICAN PSYCHIATRIC ASSOCIATION. 2010. Practice Guideline for the Treatment of Patients with Schizophrenia, Second Edition [Online]. American Psychiatric Association. Available: https://psychiatryonline.org/pb/assets/raw/sitewide/practice_guidelines/guidelines/schizop hrenia.pdf [Accessed].

AMERICAN PSYCHIATRIC ASSOCIATION. 2016. The American Psychiatric Association Practice Guidelines for the Psychiatric Evaluation of Adults, Third Edition [Online]. Arlington, VA: American Psychiatric Association. Available: https://psychiatryonline.org/doi/pdf/10.1176/appi.books.9780890426760 [Accessed].

BAIN, B. K. 1998. CT scans of first-break psychotic patients in good general health. Psychiatr Serv, 49, 234-5.

BARTHOLOMEUSZ, C. F., CROPLEY, V. L., WANNAN, C., DI BIASE, M., MCGORRY, P. D. \& PANTELIS, C. 2017. Structural neuroimaging across early-stage psychosis: Aberrations in neurobiological trajectories and implications for the staging model. Aust N Z J Psychiatry, 51, 455-476.

BATTAGLIA, J. \& SPECTOR, I. C. 1988. Utility of the CAT scan in a first psychotic episode. Gen Hosp Psychiatry, 10, 398-401.

BORGWARDT, S. J., RADUE, E. W., GOTZ, K., ASTON, J., DREWE, M., GSCHWANDTNER, U., HALLER, S., PFLUGER, M., STIEGLITZ, R. D., MCGUIRE, P. K. \& RIECHER-ROSSLER, A. 2006. Radiological findings in individuals at high risk of psychosis. J Neurol Neurosurg Psychiatry, 77, 229-33.

CHOOSING WISELY CANADA. 2017. Psychiatry: thirteen things physicians and patients should question [Online]. Available: https://choosingwiselycanada.org/psychiatry/ [Accessed].

CHOOSING WISELY UK. 2018. Royal College of Psychiatrists recommendations [Online]. Choosing Wisely UK. Available: http://www.choosingwisely.co.uk/i-am-aclinician/recommendations/\#1476656061018-6802da48-d01a [Accessed].

COENTRE, R., SILVA-DOS-SANTOS, A. \& TALINA, M. C. 2016. Retrospective study on structural neuroimaging in first-episode psychosis. PeerJ, 2016.

COMPTON, M. T., GOULDING, S. M., WHICKER, N. E., MULLINS, M., NATHAN, S. \& RESSLER, K. 2009. An exploratory study of the potential prognostic usefulness of the routinely conducted computed tomography scan in patients hospitalized for a first episode of psychosis. Clinical Schizophrenia and Related Psychoses, 3, 23-30.

FALKENBERG, I., BENETTI, S., RAFFIN, M., WUYTS, P., PETTERSSON-YEO, W., DAZZAN, P., MORGAN, K. D., MURRAY, R. M., MARQUES, T. R., DAVID, A. S., JAROSZ, J., SIMMONS, A., WILLIAMS, S. \& MCGUIRE, P. 2017. Clinical utility of magnetic resonance imaging in first-episode psychosis. $B r$ J Psychiatry, 211, 231-237.

FREUDENREICH, O., SCHULZ, S. C. \& GOFF, D. C. 2009. Initial medical work-up of first-episode psychosis: a conceptual review. Early Interv Psychiatry, 3, 10-8.

FUSAR-POLI, P. \& MEYER-LINDENBERG, A. 2016. Forty years of structural imaging in psychosis: promises and truth. Acta Psychiatr Scand, 134, 207-24.

GALLETLY, C., CASTLE, D., DARK, F., HUMBERSTONE, V., JABLENSKY, A., KILLACKEY, E., KULKARNI, J., MCGORRY, P., NIELSSEN, O. \& TRAN, N. 2016. Royal Australian and New Zealand College of 
Psychiatrists clinical practice guidelines for the management of schizophrenia and related disorders. Aust N Z J Psychiatry, 50, 410-72.

GEWIRTZ, G., SQUIRES-WHEELER, E., SHARIF, Z. \& HONER, W. G. 1994. Results of computerised tomography during first admission for psychosis. Br J Psychiatry, 164, 789-95.

GOULET, K., DESCHAMPS, B., EVOY, F. \& TRUDEL, J. F. 2009. Use of brain imaging (computed tomography and magnetic resonance imaging) in first-episode psychosis: review and retrospective study. Can J Psychiatry, 54, 493-501.

HOLLISTER, L. E. \& BOUTROS, N. 1991. Clinical use of CT and MR scans in psychiatric patients. J Psychiatry Neurosci, 16, 194-8.

JOHN, K., RICHARD, J. B. \& IAIN, E. P. 2017. A case for imaging in high-risk psychosis: insular pathology in first episode psychosis. Australian \& New Zealand Journal of Psychiatry, 51, 1057-1058.

JONSDOTTIR, H. \& BRIEM, N. 2016. First episode psychosis - The icelandic study. Early Intervention in Psychiatry, 10, 141.

KATZMAN, G. L., DAGHER, A. P. \& PATRONAS, N. J. 1999. Incidental findings on brain magnetic resonance imaging from 1000 asymptomatic volunteers. Jama, 282, 36-9.

KHANDANPOUR, N., HOGGARD, N. \& CONNOLLY, D. J. 2013. The role of MRI and CT of the brain in first episodes of psychosis. Clin Radiol, 68, 245-50.

LUBMAN, D. I., VELAKOULIS, D., MCGORRY, P. D., SMITH, D. J., BREWER, W., STUART, G., DESMOND, P., TRESS, B. \& PANTELIS, C. 2002. Incidental radiological findings on brain magnetic resonance imaging in first-episode psychosis and chronic schizophrenia. Acta Psychiatr Scand, 106, 3316.

MCKAY, D., GORRELL, J., CORNISH, A., TENNANT, C., ROSEN, A., MOSS, B. \& NASH, L. 2006. Let's get physical: an audit of medical practice in first episode psychosis. Australas Psychiatry, 14, 1469.

MOHER, D., LIBERATI, A., TETZLAFF, J. \& ALTMAN, D. G. 2009. Preferred reporting items for systematic reviews and meta-analyses: the PRISMA statement. PLoS Med, 6, e1000097.

MORRIS, Z., WHITELEY, W. N., LONGSTRETH, W. T., WEBER, F., LEE, Y.-C., TSUSHIMA, Y., ALPHS, H., LADD, S. C., WARLOW, C., WARDLAW, J. M. \& AL-SHAHI SALMAN, R. 2009. Incidental findings on brain magnetic resonance imaging: systematic review and meta-analysis. BMJ, 339.

NICE. 2011. Structural neuroimaging in first-episode psychosis [Online]. NICE. Available: https://www.nice.org.uk/guidance/ta136/documents/review-decision-june-2011 [Accessed].

ORYGEN NATIONAL CENTRE OF EXCELLENCE IN YOUTH MENTAL HEALTH. 2016. Australian Clinical Guidelines for Early Psychosis, Second Edition [Online]. Orygen. Available: https://www.orygen.org.au/Campus/Expert-Network/Resources/Free/Clinical-

Practice/Australian-Clinical-Guidelines-for-Early-Psychosis/Australian-Clinical-Guidelines-forEarly-Psychosis.aspx?ext [Accessed].

PALANIYAPPAN, L., MAAYAN, N., BERGMAN, H., DAVENPORT, C., ADAMS, C. E. \& SOARES-WEISER, K. 2015. Voxel-based morphometry for separation of schizophrenia from other types of psychosis in first episode psychosis. Cochrane Database Syst Rev, Cd011021.

PIENTKA, L. J., SCHULZ, S. C., LIM, K. O. \& JASBERG, S. G. 2017. The Clinical Impact of Neuroimaging in First-Episode Psychosis. Clin Schizophr Relat Psychoses.

RAO, S. S., OZTURK, R. \& LAINE, L. 2005. Clinical utility of diagnostic tests for constipation in adults: a systematic review. Am J Gastroenterol, 100, 1605-15.

REBECCA, K. 2014. Late onset acute psychosis secondary to primary brain tumour: An initial misdiagnosis. Australian \& New Zealand Journal of Psychiatry, 48, 1173-1174.

ROBERT WILLIAMS, S., YUKIO KOYANAGI, C. \& SHIGEMI HISHINUMA, E. 2014. On the usefulness of structural brain imaging for young first episode inpatients with psychosis. Psychiatry Research - Neuroimaging, 224, 104-106.

SOMMER, I. E., DE KORT, G. A., MEIJERING, A. L., DAZZAN, P., HULSHOFF POL, H. E., KAHN, R. S. \& VAN HAREN, N. E. 2013. How frequent are radiological abnormalities in patients with psychosis? A review of 1379 MRI scans. Schizophr Bull, 39, 815-9. 
STRAHL, B., CHEUNG, Y. K. \& STUCKEY, S. L. 2010. Diagnostic yield of computed tomography of the brain in first episode psychosis. J Med Imaging Radiat Oncol, 54, 431-4.

WEINBERGER, D. R. 1984. Brain disease and psychiatric illness: when should a psychiatrist order a CAT scan? Am J Psychiatry, 141, 1521-7. 